\title{
ŠKÁLA NEPŘIPOUTANOSTI K JÁ (NTS-CZ): PILOTNÍ STUDIE ČESKÉ VERZE
}

\author{
Jan Benda
}

\begin{abstract}
Abstrakt
Cílem této pilotní studie bylo vytvořit a validizovat českou verzi sedmipoložkové Škály nepřipoutanosti k Já (NTS-CZ) a prověřit její psychometrické vlastnosti. NTS byla nejprve $\mathrm{s}$ využitím postupu zpětného překladu přeložena do češtiny a následně byla administrována prostřednictvím webového rozhraní. 782 respondentů (165 mužů, 617 žen) vyplnilo NTS-CZ, krátkou verzi Dotazníku pěti aspektů všímavosti (FFMQ-15-CZ) a Sussexsko-Oxfordskou škálu soucitu k sobě (SOCS-S-CZ). Konfirmační faktorová analýza potvrdila jednofaktorovou strukturu NTS-CZ (SRMR = 0,037, RMSEA = 0,082, CFI = 0,972, TLI = 0,950). Hodnota Cronbachova koeficientu alfa NTS-CZ byla $\alpha=0,85$. Podle očekávání byly zjištěny vysoké pozitivní korelace NTS-CZ s dotazníky měříími všímavost a soucit k sobě. Výsledky podporují další využití NTS-CZ v psychologickém výzkumu.
\end{abstract}

Klíčová slova: nepřipoutanost, sebevztažné zpracovávání, rozpouštění ega, dotazník, psychometrické vlastnosti

\section{THE NONATTACHMENT TO SELF SCALE (NTS-CZ): A PILOT STUDY OF THE CZECH VERSION}

\begin{abstract}
The purpose of this pilot study was to develop and validate the Czech Version of the 7-item Nonattachment to Self Scale (NTS-CZ) and to examine its psychometric properties. The NTS was translated into Czech with a back-translation procedure and then administered through an online survey. 782 participants (165 men, 617 women) completed the NTS-CZ, the 15-item version of the Five Facet Mindfulness Questionnaire (FFMQ-15-CZ), and the Sussex-Oxford Compassion for the Self Scale (SOCS-S-CZ). The confirmatory factor analysis confirmed the one-factor structure of the NTS-CZ (SRMR $=0.037, \mathrm{RMSEA}=0.082, \mathrm{CFI}=0.972, \mathrm{TLI}=$ 0.950). The Cronbach's alpha coefficient for the NTS-CZ was $\alpha=0.85$. As expected, the NTS$C Z$ demonstrated high positive correlations with mindfulness and self-compassion questionnaires. The results support further use of the NTS-CZ in psychological research.
\end{abstract}

Keywords: nonattachment, self-referential processing, ego dissolution, questionnaire, psychometric properties

Došlo: 16. 4. 2020

Schváleno: 21. 10. 2020 


\section{Úvod}

Vědecký výzkum v uplynulých letech objasňuje důležitou roli sebevztažných procesů (angl. self-referential processes) v udržování duševního zdraví a rozvíjení osobní spokojenosti, ale i v etiopatogenezi řady duševních poruch (viz např. Dambrun \& Ricard, 2011; Moore et al., 2016). Ukazuje mimo jiné, že fixní, negativní jádrová přesvědčení o sobě samých a s nimi spojené pocity nedostatečnosti neboli studu se zřejmě skrývají za mnohými symptomy duševních poruch (např. Beck, 2020; Benda, 2019; Kyrios et al., 2016). Naopak flexibilnější představy o sobě samých souvisí zrejmě s vyšší odolností, seberegulací, seberealizací i sebepřesažením (srov. Brown \& Leary, 2017b). Zajímavé podněty v tomto kontextu přináší výzkum pokročilé meditace všímavosti (např. Dahl, Lutz \& Davidson, 2015; Katyal et al., 2020; srov. Vago \& Silbersweig, 2012), výzkum účinků psychedelik (např. Lebedev et al., 2015; Letheby \& Gerrans, 2017; Millière, 2017), ale i další neurovědecký výzkum (např. Frewen et al., 2020; Sui \& Rotshtein, 2019; van Oort et al., 2020).

Velmi stručně řečeno, ukazuje se, že naše představa o tom, kdo jsme, zřejmě hraje důležitou roli při vzniku mnoha psychopatologických symptomů. Rozlišují se přitom dvě podoby prožívání Já. Můžeme Já prožívat bud' jako subjekt, anebo jako objekt (např. Brown \& Leary, 2017a). Já jako subjekt, označované též jako „prožívané Já“ (Zahavi, 2011) nebo „minimální Já“ (Gallagher, 2000), je subjektem naší zkušenosti. Je prostou perspektivou toho, kdo prožívá jednotlivé smyslové a mentální fenomény tady a ted’. Já jako objekt, nazývané též „iluzorní Jáa (Zahavi, 2011) nebo „narativní Já“ (Gallagher, 2000), však vzniká díky našemu myšlení a představivosti. A právě toto „iluzorní Já“ může být zdrojem problémů. Pokud totiž věříme, že Já jako objekt skutečně existuje a má dokonce nějaké trvalé a neměnné vlastnosti, které my pak kriticky hodnotíme, stává se tato naše „představa o Já“ zdrojem (sebevztažných) pocitů méněcennosti a následně pak i mnoha dalších potíží (viz Benda, 2019; srov. Shonin, Van Gordon, \& Griffiths, 2016; Van Gordon et al., 2018). Z hlediska duševního zdraví a osobní pohody je proto důležité chápat dynamickou povahu našeho prožívání a nebýt př́liš silně „prripoutaný“ $\mathrm{k}$ nějaké statické představě o tom, jací jsme.

Ve světě jsou v posledních letech výše naznačené sebevztažné procesy intenzivně zkoumány a vznikla i řada dotazníků, které se postoj člověka k vlastnímu Já pokoušejí měřit. V psychedelickém výzkumu je využíván např́iklad Inventář rozpouštění ega (angl. EgoDissolution Inventory - EDI, Nour et al., 2016), který zachycuje změny v prožívání Já během psychedelické zkušenosti. V souvislosti s výzkumem všímavosti vznikly pak dotazníky, které se neomezují pouze na přechodný (psychedelický) zážitek, ale zachycují trvalejší způsob chápání sebe sama. Patří k nim např́klad Škála tichého ega (angl. Quiet Ego Scale - QES, Wayment, Bauer \& Sylaska, 2015), Škála vyrovnanosti (angl. Equanimity Questionnaire - EQ, Juneau et al., 2020), Škála nepřipoutanosti (angl. Nonattachment Scale - NAS, Sahdra, Shaver \& Brown, 2010) nebo Škála nepřipoutanosti k Já (angl. Nonattachment to Self Scale - NTS, Whitehead et al., 2018). A právě posledně jmenovanou škálu jsme se rozhodli převést do češtiny.

Škála nepřipoutanosti k Já (NTS) byla původně vytvořena na Swinburnské technologické univerzitě v australském Melbourne jako nástroj měřící míru flexibility a nadhledu vůči všem konkrétním představám a konceptům týkajícím se sebe sama. Byla inspirována tradiční buddhistickou psychologií, která tvrdí 1), že ve skutečnosti neexistuje žádné trvalé a neměnné Já a 2), že víra v existenci jakéhokoli trvalého a neměnného Já je významnou př́ičinou lidského strádání (srov. např. Anattalakkhaṇa sutta, SN, III, 22.59 - viz Bodhi, 2005; srov. Van Gordon 
et al., 2018). NTS sestává ze sedmi tvrzení, u nichž respondenti posuzují, do jaké míry s nimi souhlasí či nesouhlasí na sedmibodové Likertově stupnici. Škála prokázala dobrou testretestovou reliabilitu $(\mathrm{r}=0,80, \mathrm{p}<0.001,36$ dní) i kriteriální, konvergentní a diskriminační validitu. Explorační a následně také konfirmační faktorová analýza potvrdily jednofaktorovou strukturu NTS. Autoři škály přitom v testovaném modelu povolili kovariance mezi položkami 4 a 5 a položkami 6 a 7 .

\section{Cíl výzkumu a hypotézy}

Cílem této pilotní studie bylo vytvořit českou verzi Škály nepřipoutanosti k Já (NTS-CZ), přezkoumat její faktorovou strukturu, ověřit její vnitřní konzistenci a orientačně odhadnout i její konvergentní validitu. Předpokládali jsme, že škála bude mít stejnou faktorovou strukturu jako originální verze. V souladu s teoretickými předpoklady i dosavadními výzkumnými zjištěními (viz napřr. Whitehead et al., 2018) jsme dále předpokládali, že výsledky NTS-CZ budou vysoce pozitivně korelovat $\mathrm{s}$ dotazníky měřícími všímavost a soucit $\mathrm{k}$ sobě. Nepředpokládali jsme žádný významný rozdíl ve srovnání výsledků NTS-CZ mezi muži a ženami. Mezi věkem respondentů a výsledky NTS-CZ jsme očekávali nízkou pozitivní korelaci.

\section{Metoda}

\section{Výzkumný soubor}

Výzkumný soubor tvořilo 782 respondentů (165 mužů /21,1 \%/ a 617 žen /78,9 \%/), ve věku od 18 do 73 let (průměrný věk = 40,5 let, $\mathrm{SD}=10,75$ ). Mezi respondenty převažovali lidé s vysokoškolským vzděláním $(\mathrm{N}=489 / 62,5 \% /)$. Středoškoláků bylo $256(32,8 \%)$. Vyučených respondentů bylo 24 (3,1\%). Pouze základní vzdělání mělo 13 respondentů $(1,7 \%)$.

\section{Procedura}

Před započetím výzkumu jsme sedmipoložkovou škálu NTS nejprve s využitím postupu zpětného překladu (srov. Hambleton, Merenda \& Spielberger, 2004) přeložili do češtiny ${ }^{1}$. Následně jsme škálu NTS-CZ administrovali prostřednictvím webového rozhraní společně s dotazníky FFMQ-15-CZ a SOCS-S-CZ (více o těchto dotaznících dále). Dotazníková baterie byla umístěna na webové stránce mindfulness.cz určené zájemcům o všímavost a soucit se sebou. Sběr dat probíhal od zárí 2019 do dubna $2020 .^{2}$

\footnotetext{
${ }^{1}$ Na překladu se podílelo celkem pět překladatelů (včetně autora). Dva překladatelé nejprve vytvořili nezávisle na sobě dva překlady originálního dotazníku. Třetí překladatel (editor Matěj Štěpánek) následně vytvořil z těchto dvou nezávisle provedených překladů prvotní český překlad. Tento prvotní překlad byl pak přeložen zpět do angličtiny čtvrtým překladatelem, jehož mateřským jazykem byla angličtina. Autor článku pak společně s Richardem Whiteheadem a Glenem Batesem (autoři NTS) zpětný překlad do angličtiny porovnali s originálem dotazníku. Překladatelé i editor pak s autorem diskutovali, jak další úpravou české verze předejít jemným významovým posunům, k nimž došlo ve zpětném překladu. Na základě společného konsenzu pak autor, překladatelé a editor společně vytvořili finální českou verzi dotazníku.

${ }^{2}$ Počítačový program, který zaznamenával a vyhodnocoval online odpovědi respondentů požadoval po respondentech vyplnit všechny položky. Pokud některý z respondentů nevyplnil všechny požadované údaje, nezískal individuální vyhodnocení dotazníkové baterie a nebyl ani zařazen do zkoumaného souboru.
} 


\section{Nástroje}

Nepřipoutanost $k J a ́$. K měření jsme využili přeloženou Škálu nepřipoutanosti k Já (angl. Nonattachment to Self Scale - NTS-CZ, Whitehead et al., 2018). Škála sestává ze sedmi položek. Respondenti posuzovali, do jaké míry s jednotlivými tvrzeními souhlasí či nesouhlasí na sedmibodové Likertově stupnici (od $1=$ rozhodně nesouhlasím po $7=$ rozhodně souhlasím). Celková míra nepřipoutanosti k Já je vyjádřena součtem dosažených bodů.

Všimavost. K měření jsme využili zkrácenou verzi Dotazníku pěti aspektů všímavosti (angl. Five Facets of Mindfulness Questionnaire - FFMQ-15-CZ, Gu et al., 2016; česká adaptace Kořínek, Benda \& Žitník, 2019). Škála sestává z 15 položek. Respondenti posuzovali, do jaké míry pro ně platí jednotlivá tvrzení na pětibodové Likertově stupnici (od $1=$ téměř nikdy po 5 = téměř vždy). Celková míra všímavosti je vyjádřena součtem dosažených bodů.

Soucit $k$ sobě. K měření jsme využili Sussexsko-Oxfordskou škálu soucitu k sobě (angl. Sussex-Oxford Compassion for the Self Scale - SOCS-S-CZ, Gu et al., 2020). Škála sestává z 20 položek. Respondenti posuzovali, jak často pro ně platí jednotlivá tvrzení na pětibodové Likertově stupnici (od $1=$ nikdy po $5=$ vždy). Celková míra soucitu $\mathrm{k}$ sobě je vyjádřena součtem dosažených bodů.

\section{Statistická analýza dat}

K analýze dat jsme využili programy IBM SPSS Statistics-23 a Amos-23. Nejprve jsme provedli konfirmační faktorovou analýzu. K posouzení shody dat se dvěma modely posuzovanými u originální verze NTS (Whitehead et al., 2018) jsme využili indexy SRMR, RMSEA, CFI a TLI. Za akceptovatelné byly u indexů SRMR a RMSEA hodnoty $\leq 0,08$, u indexů CFI a TLI hodnoty $\geq 0,95$ (Marsh, Hau \& Wen, 2004; Schermelleh-Engel, Moosbrugger \& Müller, 2003). Přestože u posuzovaných modelů uvádíme také výsledky testi̊ chí-kvadrát $\left(\chi^{2}\right)$, s ohledem na hypersensitivitu této statistiky jsme ji k hodnocení modelů nepoužili (viz Kline, 2015). Pokud jde o deskriptivní statistiku, u každé položky NTS-CZ jsme zjistili její průměr, standardní odchylku, diskriminační sílu, faktorový náboj i Cronbachův koeficient subškály v př́ípadě, že by byla daná položka ze subškály vyloučena. Normalitu rozložení hrubých skórů NTS-CZ jsme ověřovali pomocí Shapirových-Wilkových testů. K posouzení rozdílu v celkové míře nepřipoutanosti $\mathrm{k}$ Já mezi muži a ženami jsme využili Mann-Whitneyův U-test. Souvislost mezi věkem respondentů a mírou nepřipoutanosti k Já jsme ověřovali s využitím Pearsonova korelačního koeficientu. K posouzení vnitřní konzistence NTS-CZ jsme využili Cronbachův koeficient alfa a kritéria: $\alpha \geq 0.9=$ vynikající, $\geq 0.8=$ dobré, $\geq 0.7$ = akceptovatelné, $\geq 0.6=$ diskutabilní, $\geq 0.5=$ slabé a $\leq 0.5=$ neakceptovatelné (George \& Mallery, 2013). K orientačnímu odhadu konvergentní validity NTS-CZ jsme vypočetli Pearsonovy korelační koeficienty mezi výsledky NTS-CZ a výsledky dotazníků FFMQ-15-CZ a SOCS-S-CZ. Absolutní hodnoty korelací byly interpretovány podle klíče: $r \geq 0,5=$ vysoká, $\geq$ 0,3 = střední, $\geq 0,1=$ nízká, $\geq 0$ = zanedbatelná (Cohen, 1988).

\section{Výsledky}

\section{Faktorová struktura NTS-CZ}

Konfirmační faktorová analýza metodou maximální věrohodnosti stejně jako u originální škály NTS (Whitehead et al., 2018) nepotvrdila jednofaktorovou strukturu NTS-CZ (viz tab. 1, model 1), potvrdila však model 2 s povolenými kovariancemi mezi položkami 4 a 5 a položkami 6 a 
7 (viz tab. 1, model 2). ${ }^{3}$ Faktorové náboje se u modelu 2 pohybovaly v intervalu 0,52-0,75 (viz obr. 1). Všechny byly statisticky významné, $\mathrm{p}<0,001$.

Tab. 1 Indexy shody modelů s daty

\begin{tabular}{llcccc}
\hline & $\chi^{2}(\mathrm{df})$ & SRMR & RMSEA & CFI & TLI \\
\hline Model 1 & $273,948(14)$ & 0,069 & 0,154 & 0,884 & 0,826 \\
Model 2 s povolenými kovariancemi & $75,285(12)$ & 0,037 & 0,082 & 0,972 & 0,950 \\
\hline
\end{tabular}

Poznámka: SRMR - standardizovaný kořenový reziduál průměrů; RMSEA - odmocnina z průměrného čtverce chyby odhadu; CFI - komparativní index shody; TLI - Tucker-Lewisův index.

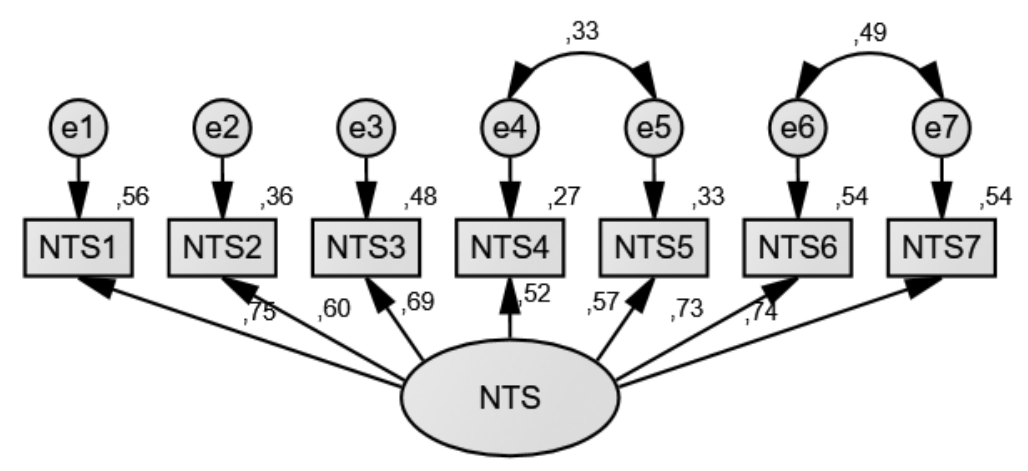

Obr. 1 Úsekový diagram modelu 2 s povolenými kovariancemi

$(\mathrm{N}=782)$, standardizované řešení

Tab. 2 Korelace mezi položkami NTS-CZ $(\mathrm{N}=782)$

\begin{tabular}{lccccccc}
\hline Položka č. & \multicolumn{1}{c}{1} & 2 & 3 & 4 & 5 & 6 & 7 \\
\hline 1 & 1 & & & & & & \\
2 & $0,46^{* *}$ & 1 & & & & & \\
3 & $0,54^{* *}$ & $0,40^{* *}$ & 1 & & & & \\
4 & $0,31^{* *}$ & $0,42^{* *}$ & $0,41^{* *}$ & 1 & & & \\
5 & $0,36^{* *}$ & $0,40^{* *}$ & $0,40^{* *}$ & $0,53^{* *}$ & 1 & & \\
6 & $0,57^{* *}$ & $0,40^{* *}$ & $0,49^{* *}$ & $0,38^{* *}$ & $0,47^{* *}$ & 1 & \\
7 & $0,59^{* *}$ & $0,41^{* *}$ & $0,48^{* *}$ & $0,36^{* *}$ & $0,44^{* *}$ & $0,76^{* *}$ & 1 \\
\hline
\end{tabular}

Poznámka: **p $<0,01$

\footnotetext{
${ }^{3}$ Položky 4 a 5 a také 6 a 7 jsou si podle autorů originální verze NTS sémanticky blízké, přesto však poukazují na mírně odlišné aspekty nepřipoutanosti k Já. Položky 4 a 7 podle autorů NTS přímo zachycují, jak lidé reagují na vlastní myšlenky o sobě samých, zatímco položky 5 a 6 zachycují aspekty Já ve zkušenosti. S ohledem na to autoři v modelu 2 povolili korelace reziduí položek 4 a 5 a také 6 a 7 (viz Whitehead et al., 2018).
} 


\section{Deskriptivní statistika}

Deskriptivní statistické údaje a některé další psychometrické charakteristiky NTS-CZ získané v našem šetření shrnují tab. 2, 3 a 4. Jak ukazuje tab. 3, všechny sledované charakteristiky jednotlivých položek NTS-CZ byly akceptovatelné. Faktorové náboje položek se pohybovaly v rozmezí 0,65-0,81. Diskriminační síla všech položek byla > 0,5 (viz tab. 3). Průměrné hrubé skóry, standardní odchylky, šikmost a špičatost NTS-CZ zobrazuje tab. 4. Podle výsledků Shapirových-Wilkových testů neměl celkový hrubý skór NTS-CZ v našem šetření normální rozdělení $(\mathrm{W}=0,993, \mathrm{df}=782, \mathrm{p}=0,001)$. U podskupiny mužů měl celkový hrubý skór NTSCZ normální rozdělení ( $\mathrm{W}=0,985, \mathrm{df}=165, \mathrm{p}=0,071)$, u podskupiny žen však nikoliv $(\mathrm{W}=$ $0,991, \mathrm{df}=617, \mathrm{p}=0,001)$. Pro další testování rozdílu mezi muži a ženami ve skórech NTS$\mathrm{CZ}$ jsme proto použili neparametrický Mann-Whitneyův U-test.

Tab. 3 Deskriptivní charakteristiky položek NTS-CZ $(\mathrm{N}=782)$

\begin{tabular}{|c|c|c|c|c|c|c|}
\hline č. & položka & M & SD & $\mathrm{L}$ & CITC & aid \\
\hline 1. & Dokážu pustit z hlavy neužitečné myšlenky o sobě samé/m. & 3,86 & 1,51 & 0,76 & 0,64 & 0,83 \\
\hline 2. & Dokážu se vzdát potřeby ovládat svůj život. & 3,42 & 1,53 & 0,67 & 0,55 & 0,84 \\
\hline 3. & Nezaplétám se příliš do myšlenek o sobě samé/m. & 3,21 & 1,56 & 0,73 & 0,61 & 0,83 \\
\hline 4. & $\begin{array}{l}\text { Jak běží čas, mám čím dál tím méně pocit, že mě definuje to, co si o sobě } \\
\text { myslím. }\end{array}$ & 3,89 & 1,54 & 0,65 & 0,54 & 0,84 \\
\hline 5. & $\begin{array}{l}\text { Jak běží čas, cítím stále menší a menší potřebu odpovídat nějaké } \\
\text { představě o tom, jaký/á bych měl/a být. }\end{array}$ & 4,33 & 1,64 & 0,69 & 0,58 & 0,84 \\
\hline 6. & $\begin{array}{l}\text { Dokážu své osobní vzestupy a pády prožívat, aniž bych se do nich př́lišs } \\
\text { zaplétal/a. }\end{array}$ & 3,68 & 1,46 & 0,81 & 0,70 & 0,82 \\
\hline 7. & $\begin{array}{l}\text { Dokážu pozorovat pozitivní i negativní myšlenky, které mám o sobě } \\
\text { samé/m, aniž bych se do nich zapletl/a. }\end{array}$ & 3,90 & 1,48 & 0,81 & 0,69 & 0,82 \\
\hline
\end{tabular}

Poznámka: M - průměr; SD - standardní odchylka; L - faktorový náboj; CITC - diskriminační síla položky (korigovaná korelace položky s celkovým skórem subškály); aid - Cronbachův koeficient subškály v př́ipadě, že by byla položka ze subškály vyloučena.

Tab. 4 Deskriptivní statistika pro celkový hrubý skór NTS-CZ $(\mathrm{N}=782)$

\begin{tabular}{lrrrrrrrrrr}
\hline \multicolumn{3}{c}{ NTS-CZ celkem } & & & & Muži & & \multicolumn{2}{c}{ Ženy } \\
& Min. & Max. & M & SD & Šikmost $^{1}$ & Špičatost $^{2}$ & M & SD & M & SD \\
\hline \multirow{2}{*}{ NTS-CZ celkem } & 7 & 49 & 26,29 & 7,82 & 0,24 & $-0,16$ & 26,02 & 8,10 & 26,36 & 7,74 \\
\hline
\end{tabular}

Poznámka: M - průměr; SD - standardní odchylka; ${ }^{1}$ - standardní chyba $=0,087 ;{ }^{2}-$ standardní chyba $=0,175 ;$ Muži: $\mathrm{N}_{\mathrm{m}}$ $=165$; Ženy: $\mathrm{N}_{\check{z}}=617$. 


\section{Rozdíly podle pohlaví a věku}

Mann-Whitneyovým U-testem jsme nezjistili v tomto šetření mezi muži a ženami statisticky významný rozdíl v celkové míře nepřipoutanosti $\mathrm{k} J a ́(\mathrm{U}=50036, \mathrm{Z}=-0,34, \mathrm{p}=0,74$; srov. též tab. 4). Mezi věkem respondentů a mírou nepřipoutanosti $\mathrm{k}$ Já jsme zjistili nízkou pozitivní korelaci $(\mathrm{r}=0,18, \mathrm{p}<0,01)$.

\section{Vnitřní konzistence}

Vnitřní konzistence měřená Cronbachovým koeficientem alfa byla u celého dotazníku NTS-CZ dobrá $(\alpha=0,85)$.

\section{Konvergentní validita}

Výsledky našeho šetření vztahující se k orientačnímu odhadu konvergentní validity NTS-CZ jsou zobrazeny $\mathrm{v}$ tab. 5 .

Tab. 5 Korelace NTS-CZ s vybranými dotazníky a jejich subškálami

\begin{tabular}{ll}
\hline FFMQ-15-CZ & $\mathbf{0 , 6 3} * *$ \\
Nereagování & $0,57^{* *}$ \\
Pozorování & $0,31^{* *}$ \\
Vědomé jednání & $0,39^{* *}$ \\
Popisování & $0,28^{* *}$ \\
Nehodnocení & $0,54^{* *}$ \\
SOCS-S-CZ & $\mathbf{0 , 6 2 * *}$ \\
Rozpoznání utrpení & $0,27 * *$ \\
Pochopení univerzality utrpení & $0,35^{* *}$ \\
Spoluprožívání trápení trpící osoby & $0,58^{* *}$ \\
Tolerance vůči nepříjemným pocitům & $0,67^{* *}$ \\
Jednání nebo motivace ke zmírnění utrpení & $0,53^{* *}$ \\
\hline Poznámka: **p $<0,01$. &
\end{tabular}

\section{Diskuse}

Jednou z největších výzev současného výzkumu všímavosti je objasnění mechanismů, jakými všímavost způsobuje změny v našem prožívání (např. Guendelman, Medeiros \& Rampes, 2017). Důležitou součástí těchto změn se přitom zdá být mimo jiné i změna v pohledu na sebe sama (Benda, 2019; Hölzel et al., 2011; Vago \& Silbersweig, 2012) a výzkumných studií zaměřených tímto směrem proto rychle přibývá. Neurovědci Dahl, Lutz \& Davidson (2015) např́íklad nedávno upozornili, že buddhistická meditační praxe vede meditující mimo jiné i k přímému introspektivnímu zkoumání sebevztažných procesů a zřejmě jim také pomáhá nahradit maladaptivní self-schémata adaptivnějšími př́edstavami o vlastním Já. Katyal et al. 
(2020) zjistili, že 1) dlouhodobě meditující si ve srovnání s kontrolní skupinou se svým Já spojovali více pozitivních adjektiv a méně negativních adjektiv a 2) jejich mozek na označení některého pozitivního adjektiva také výrazněji reagoval. Také psychologové se ale změnami sebepojímání v etiopatogenezi duševních poruch a v procesu psychoterapie intenzivně zabývají (Dambrun \& Ricard, 2011; Moore et al., 2016; Shonin, Van Gordon \& Griffiths, 2016). V uplynulých letech vznikla proto i řada sebeposuzovacích dotazníků zaměřených na postoj k vlastnímu prožívání a k sobě samému (viz např. Juneau et al., 2020; Sahdra, Shaver \& Brown, 2010; Wayment, Bauer \& Sylaska, 2015). Škálu nepřipoutanosti k Já jsme v této pilotní studii převedli do češtiny.

Psychometrické vlastnosti české verze Škály nepřipoutanosti k Já (NTS-CZ) zjištěné v této studii byly celkově velmi dobré a do značné míry odpovídaly vlastnostem původní australské verze NTS. Výjimkou byl pouze průměrný hrubý skór NTS-CZ, který byl v tomto šetření nižší $(M=26,29, \mathrm{SD}=11,17)$ než u originální verze škály $(\mathrm{M}=32,30, \mathrm{SD}=6,27$, Cohenovo d = 0,66; viz Whitehead, Bates \& Elphinstone, 2020). Protože ale velmi podobný průměrný hrubý skór NTS-CZ zjistil u nás v nezávislém šetření v souboru 391 respondentů nedávno také Štěpánek (2020, M = 26,64, SD = 6,80), můžeme se domnívat, že rozdílný výsledek nebyl způsoben nereprezentativností našeho souboru, ale dost možná kulturní odlišností australských a českých respondentů.

Faktorová struktura NTS-CZ v tomto šetření odpovídala modelu navrženém autory NTS. Faktorové náboje i další charakteristiky jednotlivých položek byly vesměs dobré. Vnitřní konzistence NTS-CZ byla dobrá $(\alpha=0,85)$ a velmi podobná jako u originální verze NTS $(\alpha=$ 0,88). Také korelace NTS-CZ $\mathrm{s}$ dotazníky měřícími všímavost a soucit $\mathrm{k}$ sobě vyšly v předpokládaném směru a měly velmi podobné velikosti jako u originální verze NTS (Whitehead et al., 2018). ${ }^{4}$

Mezi muži a ženami jsme v tomto šetření nezjistili statisticky významný rozdíl v celkové míře nepřipoutanosti $\mathrm{k}$ Já. Pouze mezi věkem respondentů a mírou nepřipoutanosti k Já jsme zjistili nízkou pozitivní korelaci. Obojí odpovídá podobným zjištěním srovnatelných zahraničních studií (srov. např. Sahdra, Shaver, Brown, 2010; Whitehead et al., 2018; Whitehead, Bates, Elphinstone, 2020).

\section{Limity studie a možnosti dalšího výzkumu}

Při interpretaci výsledků této pilotní studie je samozřejmě třeba vzít v úvahu několik omezení. Především jsme nepracovali s reprezentativním vzorkem populace. Respondenty byli především zájemci o všímavost a soucit se sebou, tedy respondenti se zvýšenou motivací a zájmem o témata reprezentovaná př́íslušnou dotazníkovou baterií. Ve výzkumném souboru nebyli dostatečně zastoupeni respondenti, kteří nevyužívají internet (podrobnější kritika internetových šetření viz např. Bethlehem, Biffignandi, 2011). Výrazně také převažovaly ženy $(78,9 \%)$ a respondenti s vysokoškolským $(62,5 \%)$ a středoškolským $(32,8 \%)$ vzděláním. Zde prezentované výsledky je proto třeba chápat jako pouze předběžné. $V$ budoucnu doporučujeme ověřit vlastnosti škály na reprezentativním vzorku české populace. $\mathrm{K}$ dalším limitům této studie

\footnotetext{
${ }^{4}$ Korelace originální verze NTS s dvacetipoložkovu verzí Dotazníku pěti aspektů všímavosti (FFMQ) byla $\mathrm{r}=0,56(\mathrm{p}<0,001)$. Korelace originální verze NTS se Škálou soucitu se sebou (SCS) byla $\mathrm{r}=0,72$ $(\mathrm{p}<0,001)$.
} 
patří pak skutečnosti, že jsme nezkoumali test-retestovou reliabilitu NTS-CZ, ani její kriteriální a diskriminační validitu. V budoucnu by tedy bylo žádoucí ověřit také tyto důležité ukazatele. ${ }^{5}$

Bylo by zajímavé srovnat míru nepřipoutanosti $\mathrm{k}$ Já různých klinických vzorků se zdravou populací, porovnat míru nepřipoutanosti $\mathrm{k}$ Já frekventantů různých terapeutických nebo seberozvojových programů před začátkem daného programu a po jeho skončení, anebo využít Škálu nepřipoutanosti k Já také při zkoumání účinků psychedelik (srov. Lebedev et al., 2015; Letheby \& Gerrans, 2017; Millière, 2017). Škálu nepřipoutanosti k Já ale každopádně jistě ocení všichni odborníci zabývající se rolí sebevztažných procesů v udržování duševního zdraví a v etiopatogenezi duševních poruch.

\section{Závěr}

Škála nepřipoutanosti k Já (NTS-CZ) prokázala v této pilotní studii celkově dobré psychometrické vlastnosti, dobrou faktorovou i konvergentní validitu a dobrou vnitřní konzistenci. Škála je připravena $\mathrm{k}$ dalšímu výzkumnému využití v českém jazyce.

\section{Literatura}

Beck, J. S. (2020). Cognitive Behavior Therapy: Basics and Beyond (3rd Ed.). Guilford Press. Benda, J. (2019). Všímavost a soucit se sebou: Proměna emocí v psychoterapii. Portál.

Bethlehem, J., \& Biffignandi, S. (2011). Handbook of web surveys. John Wiley \& Sons.

Bodhi, B. (2005). The connected discourses of the Buddha: A new translation of the Samyutta Nikaya. Wisdom.

Brown, K. W., \& Leary, M. R. (2017a). The emergence of scholarship and science on hypoegoic phenomena. In K. W. Brown, M. R. Leary (Eds.). The Oxford handbook of hypoegoic phenomena. Oxford University Press.

Brown, K. W., \& Leary, M. R. (2017b). The Oxford handbook of hypo-egoic phenomena. Oxford University Press.

Cohen, J. (1988). Statistical power analysis for the behavioral sciences. Erlbaum.

Dahl, C. J., Lutz, A., \& Davidson, R. J. (2015). Reconstructing and deconstructing the self: cognitive mechanisms in meditation practice. Trends in Cognitive Sciences, 19(9), 515523. https://doi.org/10.1016/j.tics.2015.07.001

Dambrun, M., \& Ricard, M. (2011). Self-centeredness and selflessness: A theory of self-based psychological functioning and its consequences for happiness. Review of General Psychology, 15(2), 138-157. https://doi.org/10.1037/a0023059

Frewen, P., Schroeter, M. L., Riva, G., Cipresso, P., Fairfield, B., Padulo, C., Kemp, A. H., Palaniyappan, L., Owolabi, M., Kusi-Mensah, K., Polyakova, M., Fehertoi, N., D'Andrea, W., Lowe, L., \& Northoff, G. (2020). Neuroimaging the consciousness of self: Review, and conceptual-methodological framework. Neuroscience \& Biobehavioral Reviews, 112, 164-212. https://doi.org/10.1016/j.neubiorev.2020.01.023

Gallagher, S. (2000). Philosophical conceptions of the self: Implications for cognitive science. Trends in Cognitive Sciences, 4, 12-21. https://doi.org/10.1016/S1364-6613(99)01417-5

George, D., \& Mallery, M. (2013). SPSS for Windows Step by Step: A Simple Guide and Reference 21.0. Pearson.

\footnotetext{
${ }^{5}$ Další ověření validity NTS-CZ v současné době připravuje v rámci své diplomové práce „Validizace Škály nepřipoutanosti k Já na českém vzorku“ Markéta Valtrová na FF UK v Praze.
} 
Gu, J., Baer, R., Cavanagh, K., Kuyken, W., \& Strauss, C. (2020). Development and psychometric properties of the Sussex-Oxford compassion scales (SOCS). Assessment, 27(1), 3-20. https://doi.org/10.1177/1073191119860911

Gu, J., Strauss, C., Crane, C., Barnhofer, T., Karl, A., Cavanagh, K., \& Kuyken, W. (2016). Examining the factor structure of the 39-item and 15-item versions of the Five Facet Mindfulness Questionnaire before and after mindfulness-based cognitive therapy for people with recurrent depression. Psychological Assessment, 28(7), 791-802. https://doi.org/10.1037/pas0000263

Guendelman, S., Medeiros, S., \& Rampes, H. (2017). Mindfulness and emotion regulation: Insights from neurobiological, psychological, and clinical studies. Frontiers in Psychology, 8, article: 220. https://doi.org/10.3389/fpsyg.2017.00220

Hambleton, R. K., Merenda, P., \& Spielberger, C. (2004). Adapting educational and psychological tests for cross-cultural assessment. Erlbaum.

Hölzel, B. K., Lazar, S. W., Gard, T., Schuman-Olivier, Z., Vago, D. R., \& Ott, U. (2011). How does mindfulness meditation work? Proposing mechanisms of action from a conceptual and neural perspective. Perspectives on Psychological Science, 6(6), 537-559. https://doi.org/10.1177/1745691611419671

Juneau, C., Pellerin, N., Trives, E., Ricard, M., Shankland, R., \& Dambrun, M. (2020). Reliability and validity of an equanimity questionnaire: the two-factor equanimity scale (EQUA-S). PeerJ, 8, e9405. https://doi.org/10.7717/peerj.9405

Katyal, S., Hajcak, G., Flora, T., Bartlett, A., \& Goldin, P. (2020). Event-related potential and behavioural differences in affective self-referential processing in long-term meditators versus controls. Cognitive, Affective, \& Behavioral Neuroscience, 20, 326-339. https://doi.org/10.3758/s13415-020-00771-y

Kline, R. B. (2015). Principles and practice of structural equation modelling (4th ed.). Guilford Press.

Kyrios, M., Moulding, R., Doron, G., Bhar, S., Nedeljkovic, M., \& Mikulincer, M. (eds.). (2016). The Self in understanding and treating psychological disorders. Cambridge University Press.

Lebedev, A. V., Lövdén, M., Rosenthal, G., Feilding, A., Nutt, D. J., \& Carhart-Harris, R. L. (2015). Finding the self by losing the self: Neural correlates of ego-dissolution under psilocybin. Human Brain Mapping, 36(8), 3137-3153. https://doi.org/10.1002/hbm.22833

Letheby, C., \& Gerrans, P. (2017). Self unbound: ego dissolution in psychedelic experience. Neuroscience of Consciousness, 3(1), article: nix016. https://doi.org/10.1093/nc/nix016

Marsh, H. W., Hau, K. T., \& Wen, Z. (2004). In search of golden rules: Comment on hypothesis-testing approaches to setting cutoff values for fit indexes and dangers in overgeneralizing Hu and Bentler's (1999) findings. Structural Equation Modeling, 11(3), 320-341. https://doi.org/10.1207/s15328007sem1103_2

Millière, R. (2017). Looking for the self: phenomenology, neurophysiology and philosophical significance of drug-induced ego dissolution. Frontiers in Human Neuroscience, 11, article: 245 . https://doi.org/10.3389/fnhum.2017.00245

Moore, K. E., Christian, M. A., Boren, E. A., \& Tangney, J. P. (2016). A Clinical Psychological Perspective on Hyper-and Hypo-egoicism: Symptoms, Treatment, and Therapist Characteristics. In K. W. Brown, M. R. Leary (Eds.). The Oxford handbook of hypo-egoic phenomena (pp. 95-105). Oxford University Press.

Nour, M. M., Evans, L., Nutt, D., \& Carhart-Harris, R. L. (2016). Ego-dissolution and psychedelics: validation of the ego-dissolution inventory (EDI). Frontiers in Human Neuroscience, 10, article: 269. https://doi.org/10.3389/fnhum.2016.00269 
Sahdra, B. K., Shaver, P. R., \& Brown, K. W. (2010). A scale to measure nonattachment: A Buddhist complement to Western research on attachment and adaptive functioning. Journal of Personality Assessment, 92(2), 116-127. https://doi.org/10.1080/00223890903425960

Shonin, E., Van Gordon, W., \& Griffiths, M. D. (2016). Ontological addiction: Classification, etiology, and treatment. Mindfulness, 7(3), 660-671. https://doi.org/10.1007/s12671-016-0501-4

Schermelleh-Engel, K., Moosbrugger, H., \& Müller, H. (2003). Evaluating the fit of structural equation models: Tests of significance and descriptive goodness-of-fit measures. Methods of Psychological Research, 8(8), 23-74.

Sui, J., \& Rotshtein, P. (2019). Self-prioritization and the attentional systems. Current Opinion in Psychology, 29, 148-152. https://doi.org/10.1016/j.copsyc.2019.02.010

Štěpánek, M. (2020). Soucit se sebou, stud, nepripoutanost k Já a rodičovské vzorce [Bakalářská práce]. Univerzita Palackého v Olomouci.

Vago, D. R., \& Silbersweig, D. A. (2012). Self-awareness, self-regulation, and selftranscendence (S-ART): A framework for understanding the neurobiological mechanisms of mindfulness. Frontiers in Human Neuroscience, 6, article: 296. https://doi.org/10.3389/fnhum.2012.00296

Van Gordon, W., Shonin, E., Diouri, S., Garcia-Campayo, J., Kotera, Y., \& Griffiths, M. D. (2018). Ontological addiction theory: Attachment to me, mine, and I. Journal of Behavioral Addictions, 7(4), 892-896. https://doi.org/10.1556/2006.7.2018.45

van Oort, J., Kohn, N., Vrijsen, J. N., Collard, R., Duyser, F. A., Brolsma, S. C. A., Fernández, G., Schene, A. H., Tendolkar, I., \& van Eijndhoven, P. F. (2020). Absence of default mode downregulation in response to a mild psychological stressor marks stressvulnerability across diverse psychiatric disorders. NeuroImage: Clinical, 25, article: 102176. https://doi.org/10.1016/j.nicl.2020.102176

Wayment, H. A., Bauer, J. J., \& Sylaska, K. (2015). The quiet ego scale: measuring the compassionate self-identity. Journal of Happiness Studies, 16(4), 999-1033. https://doi.org/10.1007/s10902-014-9546-Z

Whitehead, R., Bates, G., \& Elphinstone, B. (2020). Growing by letting go: Nonattachment and mindfulness as qualities of advanced psychological development. Journal of Adult Development, 27(1), 12-22. https://doi.org/10.1007/s10804-018-09326-5

Whitehead, R., Bates, G., Elphinstone, B., Yang, Y., \& Murray, G. (2018). Letting go of self: The creation of the nonattachment to self scale. Frontiers in Psychology, 9, article: 2544. https://doi.org/10.3389/fpsyg.2018.02544

Zahavi, D. (2011). The experiential Self: Objections and clarifications. In M. Siderits, E. Thompson \& D. Zahavi (Eds.). Self, No Self? Perspectives from analytical, phenomenological, and Indian traditions. Oxford University Press.

\section{Údaje o autorovi}

PhDr. Jan Benda, Ph.D. pracuje jako soukromý psychoterapeut. Zabývá se rozvíjením všímavosti a soucitu $\mathrm{k}$ sobě $\mathrm{v}$ psychoterapii a zkoumá také roli sebevztažných procesů v etiopatogenezi duševních poruch.

\section{Kontaktní údaje:}

Adresa: Katedra psychologie FF UK v Praze, nám. Jana Palacha 2, 11638 Praha 1 Email: psychoterapeut@gmail.com

Benda, J. (2020). Škála nepřipoutanosti k Já (NTS-CZ): Pilotní studie české verze. E-psychologie, 14(4), 57-67. https://doi.org/10.29364/epsy.385 